\title{
La imagen publicitaria de la actriz Magaly Solier: entre el exotismo y la re-afiliación
}

\author{
Ricardo Bedoya \\ (Universidad de Lima)
}

Recibido: $15 / 3 / 2013$

Aprobado: 20/4/2013

Resumen: El artículo analiza la imagen de la actriz peruana Magaly Solier en dos construcciones publicitarias. La primera, marcada por un estilo de exotismo primitivo que busca aprovechar los componentes étnicos de la modelo; la otra, re-significando los datos biográficos y el sentido de la presencia cultural de una actriz que ha adquirido figuración internacional. En ambos casos, el análisis busca interpretar la significación de la imagen publicitaria del personaje en relación con los discursos de pacificación del país, emprendimiento y nacionalismo que la sustentan. El texto condensa el capítulo quinto de la tesis «Madeinhuanta. Tránsitos y escenarios de Magaly Solier: la construcción de un texto cultural», con el que el autor optó el grado de magíster en Antropología Visual en la Pontificia Universidad Católica del Perú, en agosto del 2012.

Palabras clave: Imagen publicitaria / exotismo / etnicidad / filiación

\section{The actress Magaly Solier's advertising image: between exoticism and re-affiliation}

Aвstract: This article analyzes the image of the Peruvian actress Magaly Solier in two advertising constructions. The first, marked by a exoticism primitive style that seeks to leverage the ethnic components of the model; the other re-signifying the biographical data and meaning of cultural presence of an actress who has gained international figuration. In either case, the analysis seeks to interpret the significance of character's advertising image in relation to the country's peace speeches, entrepreneurship and nationalism that support it. The text condenses the fifth chapter of the thesis «Madeinhuanta. Magaly Solier's transits and scenarios: the construction of a cultural text», with which the author chose the Masterss Degree in Visual Anthropology at PUCP.

Keywords: advertising image / exotic / ethnicity / affiliation 


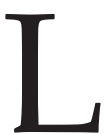
a figura de la actriz Magaly Solier es una presencia recurrente en el horizonte audiovisual de los peruanos. Su imagen se halla en la programación televisiva, en paneles publicitarios, en carteles. Más que una figura cinematográfica - el medio que la hizo conocida - su imagen se ha convertido en icono difundido en los medios y es, por eso, uno de los tantos objetos culturales de la vida ordinaria, como los estudió Raymond Williams.

¿Pero qué ha cambiado en la representación de esa imagen desde su primera película hasta la campaña publicitaria que protagonizó para la marca Nescafé en el 2010? ¿Cuáles son los factores que llevan, por ejemplo, a una mujer huamanguina a encontrarla distinta y «más bonita» en la foto de la campaña de Nescafé que en la película que la mostraba como paisana? Transcribo al respecto dos testimonios recogidos en Huamanga:

Viernes 24 de setiembre del 2010. Mercado Artesanal de Huamanga. Cinco de la tarde. En la puerta del mercado artesanal de Huamanga hay un puesto de venta de dulces, galletas y gaseosas. Me acerco a comprar una botella de agua mineral. Despacha una mujer de unos sesenta años de edad, con pollera y manto ayacuchano. Me habla con marcado acento quechua. Le pregunto si Magaly Solier ha ido por ahí, a comprar en ese mercado. «No, no ha venido, pero sí vino Gisela (aludiendo a Gisela Valcárcel)». «Seguro que no ha venido porque es huantina y no le llama la atención comprar artesanías», le digo.
«No, Magaly no es huantina, es de Huacho», me responde. Me doy cuenta de que estamos hablando de personas distintas, y que ella se refiere a Magaly Medina. «No, le pregunto por Magaly Solier, la huantina», digo. «No ha venido, pero yo la tengo aquí, en la foto de una revista», me dice mientras busca la revista entre una ruma de papeles que guarda en un costado del puesto. Guarda la revista esperando el momento en que Magaly llegue por ahí y se la firme, a modo de autógrafo. Al encontrarla, hojea la revista y señala un aviso publicitario de Nescafé. Es Magaly Solier, con vestido crema, bebiendo una taza de café durante la «pausa». Me dice: «Magaly está muy bonita ahora porque ya no está como al comienzo». «¿Y cómo era al comienzo?». «Como paisana, pues. Como en la película. Como en Madeinusa».

Viernes 24 de setiembre del 2010. Diez de la mañana. En las inmediaciones de la Plaza de Armas de Huamanga. Le pregunto a una vendedora de DVD informales qué películas ayacuchanas tiene. Me muestra algunos títulos con cierto recelo o desgano. Son melodramas de Huancayo o películas de terror de Puno. Insisto para que me muestre más y busque al fondo del depósito - una suerte de repleta canasta- que lleva consigo. Encuentra El misterio del Kharisiri junto con otros tres títulos comprimidos en discos que vende en sobres de plástico. De pronto le digo: «QQuiero una con Magaly Solier!». «Esas no están acá», me contesta. «Espera», dice, y entra a un local contiguo. Al minuto sale trayendo una copia de La teta asustada y otra de Altiplano. Cada una en sus respectivas cajas y con láminas independientes. 
«¿Por qué no las tienes juntas», le pregunto. «Son distintas», me dice. «Pero si Magaly es de acá», anoto. «Pero no es igual», responde. «Por qué?». No dice nada. Solo se sonríe y me mira esperando que le haga la oferta de compra de los DVD.

En ambas percepciones noto una reacción sustentada en la misma actitud de familiaridad inicial y extrañeza sobreviniente. Para las dos vendedoras ayacuchanas, Magaly Solier es la de «aquí» pero con un valor agregado que la altera y modifica, acaso para «embellecerla» o acaso para extrañarla. El testimonio de la vendedora del mercado artesanal celebra lo logrado por ella. Ya no luce los atuendos indígenas de Madeinusa; ahora lleva las prendas propias de una sofisticación neutra, de la puesta en escena publicitaria. Es una identidad lograda de facto, en las imágenes, al cabo de una trayectoria breve pero indiscutible. Magaly Solier, para decirlo en términos de Frederick Barth, transita entre los límites de los grupos étnicos que se confieren el derecho de juzgar la legitimidad de su pertenencia:

Pertenecer a una categoría étnica implica ser cierta clase de persona, con determinada identidad básica, esto también implica el derecho de juzgar y ser juzgado de acuerdo con las normas pertinentes de tal identidad (Barth 1976: 16).

La identificación de una persona como parte de un grupo étnico está sujeta a criterios de valoración y jui- cio que le aportan la condición de ser miembro o no, y todas las posibilidades intermedias que hay entre ser propio o «extraño».

Lo mismo ocurre con la vendedora de DVD, que retira sus películas del ámbito de los vídeos del cine regional que se venden a tres por el precio de uno. La sensibilidad de ambas mujeres repara en aquello que se ha agregado a su figura original, en los afeites añadidos y en los circuitos internacionales que asisten a sus desempeños.

\section{La casaca del exotismo}

Si miramos hacia atrás, al transcurso de su carrera, comprobamos que la trayectoria de Magaly Solier encarna la síntesis de dos construcciones: la naturalidad arraigada aunque turbulenta de una muchacha andina y la sofisticación cosmopolita de rasgos étnicos. En el trayecto, los intermediarios culturales depuran, modifican e invierten los rasgos perturbadores de sus primeros papeles de la ficción, los de Madeinusa y La teta asustada.

Paula Sibilia, en su libro La intimidad como espectáculo, ha estudiado el modo en el que las intimidades de las personas se hacen visibles en el dominio público de los medios de comunicación, construyendo subjetividades $\mathrm{y}$ creando personajes que configuran sus vidas como relatos y gestionan para sí mismos el carácter de marcas (Sibilia 2008: 303 y siguientes). En la representación mediática de la figura 
de Magaly Solier se articulan el relato de sus orígenes, de su extracción social, del ámbito geográfico del que proviene, del imaginario asociado a la provincia de Huanta que fue el escenario de los episodios violentos de hace algunos años. A partir de esos insumos, los agentes publicitarios crean las «estrategias de personificación» para ella. «Insumos» de origen que son el sustento de su «capital cultural».

Es interesante observar, por ejemplo, los rasgos de estilo primitivista al que apelan los creativos de la publicidad cuando emplean a Magaly Solier como modelo fotográfica. Esos trazos son patentes en la disposición corporal de Solier así como en el mobiliario y decorados con los que luce en las fotos, como aquella en la que modela una casaca de los almacenes Saga Falabella en su campaña de promoción de ropa invernal en la temporada del año 2008.

En junio del 2008, Saga Falabella usa por primera vez una modelo de origen andino para la publicidad de sus campañas de moda femenina de estación. Creativo de esa campaña es el publicista Juan Carlos Gómez de la Torre, de la Agencia Circus. En una entrevista, entre otros asuntos, se le pregunta sobre los motivos de la inclusión de Magaly Solier. Gómez de la Torre responde lo siguiente:

¿A qué se debe el cambio en la publicidad de Saga Falabella? [...] El primero es la agencia que se encuentra tras la realización de la publicidad; el segundo, son los recientes estudios que señalan el nuevo tipo de consumidor peruano que utiliza estos centros comerciales para realizar sus compras. $\mathrm{Y}$ el tercero, tiene que ver con la coyuntura, donde la popularidad de la actriz es innegable. [...] El otro factor tiene que ver con aquello que Rolando Arellano llama «El consumidor peruano del siglo $X X \mathrm{I} »$, que tiene que ver con el crecimiento económico experimentado por el Perú en los últimos cinco años. En este período, los diversos centros comerciales (no sólo Saga Falabella) han experimentado un crecimiento de consumo en los antes llamados conos de Lima, ahora llamados Lima Norte, Lima Sur o Lima Este, donde han levantado nuevas tiendas. Igual ha sucedido con las principales ciudades del Perú [...]. Así lo revela un estudio elaborado por Arellano Márketing, que detalla que la penetración de los centros comerciales de Lima creció de 66\% en 2007 a 75\% en 2008 (en el Cono Norte, la penetración alcanzó $98 \%$ ). Dicho crecimiento fue impulsado fundamentalmente por los niveles socioeconómicos C y D. Estos consumidores buscan atender sus necesidades básicas, como la alimentación y el esparcimiento. ¿Existe un desplazamiento económico, nacido de sectores populares, que esté obligando a estos centros comerciales a adecuar sus perfiles publicitarios al nuevo escenario nacional? Pues parece que sí y ya era hora [...]. Finalmente, el tercer punto que ha permitido la afortunada decisión para que la publicidad peruana empiece a cambiar (claro que una golondrina no hace el verano) es la aparición de una muchacha como Magaly Solier, quien no sólo ha sorprendido por su innato talento 
actoral y musical, sino que no se calla ante lo que considera un acto de injusticia [...] (Pospost, en línea).

Acuclillada en un recodo de un bosque cubierto de nieve, en un gesto apacible y neutro, maquillada a la usanza habitual, con las cejas depiladas en arco y los ojos delineados. Esa es la pose elegida. Se pueden ver las ramas de un árbol hacia el fondo de la imagen y un tronco a sus espaldas. El cabello termina en una trenza adornada con pompones de lana de «colores étnicos» que aportan a su apariencia un aire de compostura más bien contrita, de gesto ingenuo. La iluminación es envolvente, pareja, neta, y el tratamiento cromático del conjunto visual se enfría por la presencia del elemento central de la decoración: la nieve. La escenografía de estudio simula una localización exterior congelada: es el entorno «primitivo» que se dispone para que Magaly Solier modele ropa invernal. La foto con la casaca de Saga Falabella siembra exotismo en el ambiente para que guarde relación con sus rasgos faciales. ${ }^{1}$

Un tipo especial de modelo, caracterizada por su etnicidad «diferente», requiere de un entorno que evoca a la vez el nativismo de culturas asociadas con el dominio de la naturaleza: quedan patentes los rigores del clima, del ambiente y la severidad del frío. Acaso andina, acaso esquimal, acaso lapona, acaso tibetana, la foto representa un modelo de belleza exótica afincada en un espacio que requiere domeñarse. La imagen de la joven agazapada en la nieve y entre troncos caídos que cubren su cuerpo para protegerse de los rigores de lo elemental remite a un imaginario de espacios lejanos y hasta remotos, sobre todo para un lector del diario El Comercio, de Lima, con el que se distribuyó la foto en un catálogo repartido como encarte del periódico. La representación tradicional del nativo está ligada a una relación primaria con lo natural, ya que el contacto con un mundo de sensaciones primordiales lo «alteriza» a los ojos del destinatario urbano de la imagen, sobre todo si es publicitaria. ${ }^{2}$

Y a ello aporta la híper-ritualización que observa Goffman en la representación publicitaria de la imagen femenina (Goffman 1991: 167).

La normalización del lugar agreste se dispone para una modelo diferente. $\mathrm{Y}$ para aprovechar sus rasgos faciales se extrema la representación del clima invernal y del lugar, pese a que es una campaña publicitaria destinada a consumidores limeños, ajenos a los rigores del frío extremo. La simplicidad de lo natural exige la reducción casi

1 Véase la imagen en: <http://www.cinencuentro.com/wp-content/uploads/2008/06/ magaly1000.jpg>.

2 Sobre el exotismo, el primitivismo y la representación de la alteridad, véanse Appadurai (2001) y Ashcroft, Griffiths y Tiffin (2007: 87). 
minimalista de los elementos escenográficos tanto como del gesto mismo de la modelo.

Es una representación de la alteridad que pasa por alto la apelación a la sensualidad propia de las modelos de rasgos caucásicos u «occidentales», explotada por la publicidad usual. En una entrevista, el psicoanalista Julio Hevia observa que en las imágenes publicitarias Magaly Solier aparece con una configuración corporal cilíndrica, tubular, de tinaja, que es el referente visual con el que se representa a la mujer andina. La indumentaria la torna asexuada e intemporal ya que carece de marcadores (Hevia 2010). ${ }^{3}$

En las imágenes publicitarias de Magaly Solier el entorno escenográfico la desarraiga. En esas fotografías, la voluptuosidad está erradicada. La armonía de su rostro o su belleza facial son rasgos para admirar pero no para desear. Hay que anotar que esta representación exótica y lánguida de una joven de rasgos étnicos marcados pero de nombre conocido, figura identificable y fama internacional, difiere de aquella predominante en el folclor híbrido destinado a los turistas, que subraya la «sexualidad» de las participantes en coreografías de danza que recalcan los modales agresivos y las formas torneadas de las mestizas, tal como lo estudió Marisol de la Cadena (2001: 183).
Luego de su experiencia como modelo para fotografías publicitarias y de su participación en el Festival de Berlín del 2009, en la entrega del Óscar del año 2010, así como en el rodaje de varias películas de producción internacional, Magaly Solier se convierte en una de las figuras que ilustra el discurso de revalorización de lo nacional y promoción del empeño y el éxito que se difunde con insistencia en estos años, promovido por el Estado y agentes operativos diversos. Solier encarna, en ese horizonte, los valores de sensibilidad, ánimo triunfador, inteligencia y carisma que se pretenden naturales en una mujer andina, huantina para más señas, descendiente de campesinos quechuahablantes y víctimas de una violencia política ya superada.

A su turno, Solier recibe de ese reconocimiento e identificación una percepción de la significación de su propio trabajo artístico y de la conciencia de su capacidad de irradiación sobre el entorno. Lo que la abre a la idea de un «compromiso» con sus raíces culturales, una etnicidad particular, sin menoscabo de la identidad urbana, hispanohablante y hasta cosmopolita que va construyendo. El movimiento es de síntesis de contrarios. El mestizaje cultural debe por igual a los orígenes campesinos y a los modales urbanos, a los reclamos de la tierra y a la fidelidad hacia la madre y el impulso hacia

3 Anotemos también que ese «cuerpo sin marcadores» es el que registran las fotos de Solier publicadas por la revista Caras, que aparecen en la edición de marzo del 2010. 
la modernidad. Lo que acaso se ilustra con esta observación:

[...] lo que usualmente llamo lo global, lejos de ser algo que, de un modo sistemático, cubre todo creando similitud, en realidad funciona a través de la particularidad, negocia espacios particulares, etnicidades particulares, funciona a través de movilizar identidades particulares, etc. Entonces siempre hay una dialéctica, una dialéctica continua, entre lo local y lo global (Hall 2010: 332).

\section{El Nescafé de la «sanación»: filiación, afiliación, re-filiación}

Motivo constante en las representaciones fílmicas y en la autorrepresentación de Magaly Solier, así como recurso central de su capital cultural, es la relación con su madre biológica, Gregoria Romero, pero también con lo que connota el concepto simbólico de «madre», es decir, las nociones de ligazón, entronque, filiación, herencia y, por extensión, las vinculaciones con la tierra y lo ancestral. La madre representada a lo largo de la trayectoria de Magaly Solier cimenta una emoción personal, una noción de intimidad y una posibilidad de evocar recuerdos dolorosos o placenteros, de acuerdo con el contexto. Construcción que sirve también como referencia para ubicar el lugar que ocupa el personaje de la actriz ahora globalizada, una Solier que mira con afecto, pero desde la distancia, sus orígenes, porque ya está situada en otro lugar y afiliada a otros mundos.

La filiación con la madre y la tierra mantiene su pertenencia a la comunidad cultural de la que proviene aunque su situación actual la haya vinculado con otras dimensiones geográficas y con prácticas culturales distintas.

Los conceptos de «filiación/afiliación», provenientes de Edward Said (1983: 31), se han empleado en los estudios poscoloniales para designar las líneas de descendencia «natural» (filiación), y los procesos de identificación a través de la cultura (afiliación) (Ashcroft, Griffiths y Tiffin 2007: 96). ${ }^{4}$

La «filiación/afiliación» son términos operativos en esta relación de Magaly Solier con su madre y con el mundo imaginario que deja, con el alternativo al que llega y con el natu-

4 Gustavo Faverón Patriau lee, a la luz de estas categorías, algunos relatos literarios peruanos que abordan el asunto de la violencia política, y dice sobre ello: «La constatación de esa recurrente presencia de las "dificultades de la filiación", producida en el trance del aislamiento y la fragmentación del sujeto en la tardía modernidad occidental, conduce a Said a interrogarse sobre la alternativa a la filiación natural, es decir, sobre la afiliación: la inclusión del individuo en un colectivo en razón de afinidades ideológicas, políticas, de clase, etc. No una pertenencia natural sino una voluntaria y a veces electiva» (Faverón 2006: 16). 
ral al que vuelve. El anuncio publicitario de Nescafé (YouTube, en línea) no solo define el «lugar» que Solier ocupa en el momento de la difusión masiva del spot (mayo del 2010), sino que encarna la relación entre las nociones de «filiación»y «afiliación», para agregarle un concepto adicional, el de «re-filiación».

En Madeinusa, el personaje de Solier rechaza la tradición del incesto, servidumbre impuesta por la «filiación» natural para intentar la «afiliación» en Lima. En La teta asustada, la «filiación» del personaje de Fausta trae consigo una relación conflictiva con su memoria ancestral, siendo la «afiliación» el resultado de la integración de Fausta a un nuevo medio al cabo de un «rito de pasaje». El anuncio de Nescafé vincula los dos conceptos de un modo sintético.

El spot publicitario de Nescafé, emitido desde mayo del 2010, empieza describiendo el «lugar» que ocupa Solier como actriz, como persona $y$ como figura mediática: en pleno rodaje de una película, maquillada y asistida por técnicos, rodeada por luces y por una cámara que gira en travelling por un riel, Magaly Solier, luego de identificarse con su nombre y apellido en la «sobrevoz» o voice over que hace la narración, dice que necesita darse una pausa Nescafé. La locución es hecha por ella misma; es su voz con marcas orales de un castellano de acento quechuizado. Al beber de la taza, el sabor y el aroma del producto la conducen de un modo imaginario - el entorno se paraliza y el movimiento del entorno, salvo el suyo, se congela- a un lugar que, según dice, la «conecte conmigo misma». Camina por parajes andinos y llega a un destino, que es el de su «inspiración»: encuentra a su madre haciendo labores domésticas dentro de una casa ubicada en el campo.

Alejandro Guzmán, director creativo asociado de McCann Erickson Perú, agencia publicitaria responsable de la campaña Nescafé, explica que el motivo genérico de la campaña llamada «Pausa Nescafé» es interiorizar en una persona común e imaginar lo que siente al hacer un alto para paladear una taza de café (Guzmán 2010). En spots anteriores de la marca, los personajes de la campaña encarnaban figuraciones amplias, representaciones genéricas de tipos humanos, sociales o laborales, como el ama de casa, el padre de familia, los muchachos universitarios, el oficinista o el empleado de un banco. Se cumplía así la intención de dotar al anuncio de un contenido emotivo asociado al concepto de la «pausa Nescafé» para indagar en la subjetividad de esa cifra genérica o anónima que es la persona que desempeña una tarea cotidiana. La primera persona pública que realiza un anuncio de esta campaña es Magaly Solier, lo que le da una orientación distinta, apelando a una «historia real», una «historia de vida»: la de la relación de la actriz con su madre, tal como la ha narrado en diversas entrevistas. Mejor dicho, re- 
creando y reconstruyendo, pero también simbolizando esa relación. ${ }^{5}$

El concepto primordial desarrollado por los creativos publicitarios consiste en dar forma a lo que Solier, figurada como actriz de cine y personaje conocido por el público, percibe de modo subjetivo e ideal cuando queda ensimismada por la «pausa Nescafé». Luego de un viaje interior, aparece la madre.

Los creativos de McCann Erickson Perú diseñan el spot con una intención definida: que desde la imagen inicial se perciba, a simple golpe de vista, que la actriz está filmando una película con un equipo de rodaje extranjero. Para ello se apela al estereotipo fisonómico racial caucásico de los participantes en los papeles del director y técnicos de la película que se realiza. Otra intención: representar a Solier como la «estrella» de la producción que, por ende, recibe todas las atenciones del peinador y la maquilladora. Es entonces, luego de ver esas imágenes y reconocer el estatus de la actriz, que Magaly Solier se identifica con su nombre y apellido, apelando a su reconocimiento por los destinatarios del mensaje publicitario. Como ejerciendo el poder que le confiere ese estatus, Solier detiene el rodaje para hacer una pausa y tomar café. Lo hace mediante un gesto de decisión y orden que resulta escueto pero suficiente. Hemos visto la imagen de una mujer triunfadora y de una actriz internacionalizada.

Gracias al aroma y al sabor del café, atraviesa el puente de su imaginación para llegar a la casa de la campiña, en un paisaje idealizado que remite al locus amoenus del imaginario pastoral. ${ }^{6}$ La madre se encuentra ahí. «Es la casa que me gustaría tener, a la que me gustaría llegar cuando voy a Huanta», dijo Magaly al ver la localización en Canta, donde se grabó ese segmento del spot (Guzmán 2010).

El anuncio publicitario resume el tránsito del personaje. Muestra una «representación» explícita, una performance: vemos a Magaly Solier encarnando a Magaly Solier. Ya no es la actriz que representa a los personajes de Madeinusa o Fausta. Es ella mis-

5 Luego de la campaña con Magaly Solier, Nescafé lanza otro anuncio apelando a la «historia de vida» del periodista y conductor televisivo Mauricio Fernandini, campeón nacional de marinera en la categoría senior. El anuncio se dirige a un sector distinto y específico de consumidores, de edad media mayor, y lo interpela a partir de los motivos de la salud conservada gracias a la actividad física y a los antioxidantes contenidos en el café. Pero es significativo que el anuncio retome los elementos propios del repertorio de los valores nacionales que se exaltan en el discurso oficial del país como marca. En este caso, de los atributos señoriales de la danza costeña.

6 Locus amoenus es un concepto que designa el «lugar adorable» de la literatura pastoral clásica latina, como en las Bucólicas, de Virgilio. Véase Curtius (1990). 
ma ubicada en la encrucijada de dos dimensiones, o acaso encarnando la síntesis de dos construcciones. Narra el viaje inverso de los migrantes hacia la capital y relee la imagen de Solier a la luz de los conceptos de filiación/ afiliación.

La agencia creativa del spot trabaja la idea del «espacio» y su representación en la consolidación de la figura mediática de Solier retomando los motivos centrales de las películas realizadas por ella, sobre todo de La teta asustada, para volverlos a significar, invirtiendo sus valencias, otorgando otros sentidos a sus imágenes, aludiendo a un imaginario creado con anterioridad (el de la mujer afectada por el síndrome del miedo) para construir uno alternativo, es decir, practicando una hipertextualidad que relaciona «un texto B (hipertexto) a un texto anterior A (hipotexto)» (Genette 1982: 13). Analicemos cuáles son esas relaciones, prolongaciones, inversiones $\mathrm{y}$ diferencias.

Las primeras imágenes del spot de Nescafé se ambientan en el centro his- tórico de Lima, donde se ve a Solier filmando una película. No olvidemos que Madeinusa termina con el personaje principal saliendo de Manayaycuna, pueblo gobernado por las pulsiones de la violencia y la amenaza del incesto. El personaje rompe con su filiación para acceder al cambio y a la modernidad. En La teta asustada, hija de una desplazada, Fausta se mueve por territorios periféricos de la capital para lograr desde ahí, en un tránsito complejo, una afiliación a la Lima de la mezcla cultural.

El spot publicitario de Nescafé, en cambio, ubica a Magaly Solier, desde su primera imagen, en el Centro Histórico de Lima, ese espacio simbólico de la República peruana y de una Lima criolla pero polivalente de acuerdo con las épocas. ${ }^{7}$

El espacio urbano que rodea esas imágenes de Magaly Solier convertida en una estrella de cine asistida por maquilladores y técnicos le proyecta un entorno significativo y cargado de valencias complejas y simbólicas. Ella aparece inscrita en el corazón mismo

7 Para ceñirnos solo al transcurso del siglo XX, el entorno urbano que registra el anuncio publicitario es el del centro histórico de la ciudad que lució como encarnación de la modernidad urbana edificada por el Régimen de la Patria Nueva, heredera de los rastros de la arquitectura afrancesada impuesta como canon y patrón dominante en el período de la «República Aristocrática» y decantada en las rutinas del Palais Concert. Luego, el que fue escenario de la inauguración de inmuebles emblemáticos y signos de la inversión de capitales norteamericanos en el Perú durante los años treinta del siglo XX, como el lujoso cine de la Metro Goldwyn Mayer, entre otros edificios que modelaron un imaginario de prosperidad del país, aparejado con el incremento de las actividades de las finanzas y el comercio. Años después, el que se convirtió en epicentro de la bohemia modernista y de la intelectualidad existencialista, las contorsiones de las rumberas y la fiebre del mambo en 
de un imaginario republicano que admite ahora a la «huantina de corazón», como se define en su página oficial de Facebook.

En una entrevista personal mantenida con Magaly Solier, evocó sus primeras impresiones y fantasías acerca de Lima, imaginada desde Huanta:

En Huanta siempre oí decir: me voy a Lima o voy para Lima. Todos mis compañeros de colegio iban de vacaciones para Lima o muchos se fueron para vivir en Lima. Y yo le decía, «la famosa Lima». Luego de la primera película, he venido para Lima, pero no estoy mucho tiempo aquí porque viajo al extranjero o voy a ver a mi mamá. En Lima hay muchos carros, mucha contaminación, pero está el mar que es lo más bonito. Me he dado cuenta que en Lima está toda la tecnología y lo que se necesita para hacer cosas. Pero hay que saber hacerlo (Solier 2010).

En las imágenes del spot de Nescafé, Magaly Solier ya ha «conquistado» la «famosa Lima» y lo proclama al decir su nombre, que es una forma de marcar un territorio y mencionar un poder ejercido mediante el acto de detener el rodaje para tomar una pausa.
Se ha afiliado a un medio, ha adoptado una red de asociaciones culturales, formas, jerarquías, símbolos, imaginarios estéticos, instituciones, agencias y fuerzas sociales que no son las que recibió en herencia, en filiación. Su agencia personal, su fama adquirida y su figuración pública la han llevado por otros territorios.

Pero el aroma y el sabor del café, a los que ella convoca cuando quiere, la conducen a recorrer el camino inverso al seguido para llegar hasta donde está, el rumbo de vuelta hacia su casa, a los orígenes, en ese mundo rural andino que ya no luce acosado por roedores como en Madeinusa.

En el trayecto, el entorno se detiene, los movimientos se paralizan, los actos de los figurantes se congelan en derredor. El mundo parece fijarse en una instantánea de eternidad. La única que mantiene el paso, el ritmo y la dinámica es ella, Magaly Solier, a la que vemos caminar por el Puente de Piedra o Puente Trujillo, con el cerro San Cristóbal como imagen escenográfica de fondo.

el Embassy durante los años de la segunda posguerra europea, así como también escenario de las luchas políticas de resistencia a la dictadura de Odría, nucleadas en torno a la Universidad de San Marcos. El que cobijó diversas protestas sociales, como la que estalló con violencia el 5 de febrero de 1974 (durante la «primera fase» del gobierno militar presidido por el general Velasco Alvarado). El que fue testigo impotente de la progresiva deserción de las sedes de las empresas ahí situadas, que enrumbaron hacia el sur y hacia el este de la ciudad. El que fue escenario del «desborde popular» registrado en películas peruanas de los años ochenta, como Gregorio y Juliana, del Grupo Chaski. El que dio lugar a experiencias de recuperación del espacio urbano en décadas recientes. 
La muchacha andina que camina con paso seguro por escenarios de la Lima tradicional adquiere un sentido simbólico particular: es ahí, en esa escenografía urbana, que ha adquirido visibilidad y presencia a pesar de su etnicidad y filiación original. Ella, en su recorrido, desafía esa geografía de

[...] identidad localizada y territorializada que ha sido instrumental a un orden político y cultural en el que Lima se constituye como el centro del Estado-nación y el resto del país como un paisaje fragmentado, un territorio distante e internamente desconectado (Cánepa 2007: 29).

La representación de ambientes icónicos de Lima, ciudad que recibió el mayor volumen de emigrantes andinos en los sucesivos flujos de desplazamiento desde mediados del siglo pasado, se carga de sentido si contrastamos los imaginarios arraigados en las dos figuras que coexisten en las imágenes de Solier cruzando el Puente de Piedra: el símbolo de la Lima tradicional, la de Bajo el Puente y el San Cristóbal dominando la ciudad, y la de la muchacha salida de Huanta, donde Claudia Llosa la encontró vendiendo «puka picante» para financiar el viaje de su promoción escolar. Es la trayectoria de la re-filiación cultural. El nuevo entronque.

La publicidad de Nescafé fusiona «lo real» y la ficción y usa los espacios tangibles o imaginarios para reformular a Magaly Solier que habla de sí mis- ma, desde el nuevo estatus logrado, y parte en busca de la «inspiración de su vida»: la madre. Se suceden las representaciones de la tierra, el ambiente, el refugio, el origen, pero después de la «limpieza» y la «sanación». Vemos a la madre en el interior de la casa, mientras cocina. El clima del lugar está significado por la luz que entra, filtrada, por la ventana.

¿Dónde se ambienta el encuentro de las dos mujeres? En un paraje serrano, de luz intensa, cielo celeste, verdes campos. Ahí está enclavada la casa rural, con humo que sale por la chimenea. Espacio que moviliza el imaginario de los destinatarios del spot: es la muchacha del campo que vuelve a su lugar de origen. Se apela a la narrativa de los inicios. Las imágenes aluden a la Huanta referida en los relatos de Magaly Solier, lugar donde ella cultiva la tierra de su familia, como en su performance televisiva el día que se anuncia la candidatura de La teta asustada al Óscar de la Academia de Hollywood, en enero del 2010. Ese volver a la tierra, aun en el triunfo, es convertido en «metáfora» por el spot de Nescafé, cerrando tal vez el círculo de una biografía personal convertida en emblema. Es la imagen de una persona que logra triunfar manteniendo vigentes y en plena coexistencia sus hábitats de significado.

David Harvey ha señalado la condición de un espacio aniquilado por el tiempo en la posmodernidad (Harvey 
2004: 299). En el spot de Nescafé el espacio también es aniquilado por el tiempo, esa dimensión subjetiva que contrae las horas reales en una experiencia instantánea que dura el transcurso de una «pausa». Es el paisaje al que se retorna de modo imaginario, una geografía afectiva y mental, el heimat o terruño que vive en la mente, en el recuerdo, idealizado, más allá de la suma de experiencias internacionales del sujeto. La valoración del sitio, el restablecimiento del vínculo con la geografía esencial, es el síntoma encarnado en una tendencia contradictoria a la homogeneización cultural detectada por Stuart Hall, que escribe:

[...] junto a la tendencia de homogeneización global existe una fascinación por la diferencia y la comercialización de la etnicidad y de la «otredad». Hay un nuevo interés en lo «local» que acompaña el impacto de lo «global». La globalización (en la forma de especialización flexible y mercadeo de «nichos») realmente explota la diferenciación local. De esta manera, en lugar de pensar lo global reemplazando a lo local, sería más adecuado pensar en una nueva articulación entre «lo global»y «lo local» [...] es muy poco probable que la globalización destruya las identidades nacionales. Es más probable que produzca, simultáneamente, nuevas identidades «globales» y nuevas identidades «locales» (Hall 2009: 392).

En el spot de Nescafé, la madre realiza tareas domésticas dentro de una casa andina de ventanas abiertas y luz transparente filtrada. Ambientes que lucen tonos cromáticos muy puros, ambientación atmosférica, brillantez particular en la imagen, figuración pastoral que forma parte de una evocación que es a la vez nostálgica y lírica. El terruño es un sitio vivido a través de una percepción teatralizada y simbólica: es la matriz que genera y preserva una cultura y una comunidad. Se despoja, en la representación, de sus valencias puramente físicas para adquirir el sentido de un «lugar espiritual».

Esos parajes serranos ya no son escenarios de muerte, violación, incesto o miedo, como en las películas de Claudia Llosa o como en la memoria a la que apeló Yuyanapaq. Son, más bien, espacios de una Arcadia local, de las querencias primarias, de los valores restablecidos y los miedos exorcizados y antagónicos a los de Madeinusa y $L a$ teta asustada. A ellos se puede volver gracias a una «pausa Nescafé».

Bien puede contrastarse la visión pastoral del spot con lo observado en una casa de la clase media huantina, y en el testimonio de su propietaria, en visita que hice a Huanta en setiembre del 2010. En torno del patio de la casa huantina se disponen dormitorios y estancias. Al fondo, hacia el costado derecho del predio, hay otras construcciones, propiedades de terceras personas. Maestra jubilada, la propietaria del inmueble vive con una hija y su nieto pequeño. Señalando el in- 
terior del predio, cuenta que las casas en Huanta tuvieron que dividir sus espacios e independizarlos a causa del crecimiento urbano. «Se construyó en lo que eran enormes huertos y donde se sembraban frutales». Pero no solo la necesidad de aprovechar la mayor rentabilidad del espacio llevó a eso. También lo motivó la falta de mano de obra para sembrar y cosechar:

Ya no se consigue gente que trabaje la tierra. Antes, los empleados de la casa traían familiares para hacerlo, pero ahora no. Los jóvenes se van a Ayacucho a estudiar o a trabajar, emigran a Lima, o muchos van hacia la selva, donde sus padres migraron en la época del terrorismo y son dueños de parcelas donde cultivan coca. Esos jóvenes luego regresan a Huanta y construyen enormes casas, hostales o ponen negocios de tres o cuatro pisos. Son las casas y negocios de los «nachos», como se les llama aquí a los narcotraficantes.

Ahora bien, la Magaly Solier emprendedora y triunfadora del spot es un personaje reconciliado, que no está de espaldas a Cristo como en Madeinusa, ni padece del miedo ancestral heredado por la leche materna que mana de una teta asustada. La madre hacendosa ahora está sana y la tierra también. Las imágenes del anuncio publicitario se asimilan a los «discursos legitimadores» de «los peruanos» triunfadores que se reproducen en los medios de comunicación y se difunden desde las oficinas de promoción estatal del turismo, teniendo como sustento los es- tudios sobre el comportamiento de los consumidores (Fecé Gómez 2004: 386).

Se produce una articulación perceptible entre las expectativas de sectores de consumidores emergentes y la necesidad de posicionarse en el mercado global desde la experiencia de lo local. El sociólogo Santiago Alfaro Rotondo observa a la Magaly Solier modelada por la publicidad como el producto de dos impulsos. Uno, de promoción interna, dada la modificación del consumo de los peruanos durante la primera década del siglo XXI, con sectores emergentes que demandan nuevas representaciones de ellos mismos. El otro impulso es el que ofrece la imagen de Magaly Solier al mercado internacional, como producto de la globalización, ese espacio al que el Perú busca integrarse con un rasgo de diferencia exótica. Ella se convierte, en esta confluencia de impulsos, en la encarnación de uno de los «nuevos héroes» propuestos por la idea de difusión y reafirmación de la peruanidad actual a escala global y en embajadora de la Marca Perú, ese producto del branding diseñado por la estrategia de la mercadotecnia estatal (Alfaro 2010).

En ese horizonte, la pausa globalizada de Nescafé supone la representación de un retorno de lo ancestral, lo primario, lo remoto y lo local. La fantasía de la vuelta al hogar. La autorrepresentación mediática de Magaly Solier en la publicidad, en la Berlinale o en «Yuyanapaq» luce 
afincada, «fechada», «histórica», aclimatada, a diferencia, por ejemplo, de las representaciones de Yma Súmac, la cantante que performó lo local andino en el mundo del espectáculo de hace seis décadas. Si Solier remite a una Huanta localizada, la presencia y atavíos de Yma Súmac evocaban un mundo incaico imperial, intemporal, milenario, telúrico, legendario, construido a la medida de las expectativas de las audiencias internacionales del Hollywood de cartón piedra de mediados del siglo pasado.

Solier, en cambio, está enraizada a una narración particular, que es la de una «comunidad imaginada» como alternativa a aquella turbulenta de hace dos décadas, pero ahora recuperada, reivindicada, sana:

Las culturas nacionales están compuestas no solamente de instituciones culturales, sino también de símbolos y representaciones. Una cultura nacional es un discurso, una manera de construir significados que influencia y organiza tanto nuestras acciones como la concepción de nosotros mismos. Las culturas nacionales construyen identidades a través de producir significados sobre la «nación» que podemos identificar; éstos están contenidos en las historias que se cuentan sobre ella, las memorias que conectan su presente con su pasado, y las imágenes que de ella se construyen. Como sostuvo Benedict Anderson, la identidad nacional es una «comunidad imaginada» (Hall 2010: 381).
Para esa construcción se utilizan estrategias narrativas que el propio Hall resume en cinco categorías: la narrativa de la nación; el énfasis en los orígenes, la continuidad, la tradición y la eternidad; la invención de la tradición, según terminología de Eric Hobsbawn y Ranger; el mito fundacional, y la idea basal de un «pueblo de gente pura y original».

Sin forzar las homologías, se puede encontrar en la Magaly Solier propuesta por la publicidad de Nescafé al personaje capaz de protagonizar los relatos edificados a partir de las estrategias narrativas de construcción imaginaria de una comunidad: allí encontramos la imagen de la muchacha triunfadora que recorre espacios emblemáticos de la costa y paisajes serranos de belleza pastoral que encarnan una idea de nación antigua, fusionada, unida a través de un puente que se atraviesa de modo fluido. Allí están los paisajes que preexisten desde mucho tiempo atrás y que subsistirán. Allí está también la imagen de la muchacha huantina que vive su infancia durante la guerra interna y que ahora regresa a los parajes de siempre, demostrando que la continuidad de la nación no se ha quebrado a pesar de la violencia. Allí está la idea de una comunidad que se funda en el hogar, al lado de la familia, y que se vislumbra en el tiempo mítico de los recuerdos y las entrañables evocaciones: madre 
sencilla, sana, ajena a las tragedias de la historia, recuperada del pasado, original y pura. Y más allá de cualquier incitación imaginaria o apelación a la fantasía, está la presencia neta de Magaly Solier nombrándose y señalando su «lugar en el mundo», su tránsito, fama y reconocimiento mediático. Es el anclaje de su destino individual en la narración de «todos».

\section{Bibliografía}

Alfaro Rotondo, Santiago (12 de septiembre de 2010). Entrevista personal. Lima.

Appadurai, Arjun (2001). La modernidad desbordada: dimensiones culturales de la globalización. Montevideo: Trilce.

Ashcroft, Bill; Griffiths, Gareth y Helen Tiffin (2007). Post-colonial studies: The key concepts. Nueva York: Routledge.

Barth, Frederick (1976). Los grupos étnicos y sus fronteras. La organización social de las diferencias culturales. México D.F.: Fondo de Cultura Económica.

Cánepa Koch, Gisela (ed.) (2007). «Geopoética de identidad y lo cholo en el Perú: migración, geografía y mestizaje». Crónicas Urbanas 13. Centro Guamán Poma de Ayala.

Curtius, Ernst Robert (1990). European literature and the latin middle ages. Nueva Jersey: Princeton University Press.
De la Cadena, Marisol (2001). «Mestizos-indígenas. Imágenes de autenticidad y des-indianización en la ciudad del Cuzco», en Cánepa Koch, Gisela (ed.). Identidades representadas: performance, experiencia y memoria en los Andes. Lima: Pontificia Universidad Católica del Perú.

Faverón Patriau, Gustavo (2006). Toda la sangre: antología de cuentos peruanos sobre la violencia politica. Lima: Matalamanga.

Fecé Gómez, Josep Lluís (2004). «Antonio Banderas: análisis del starsystem como producto cultural», en Ardévol, Elisenda y Nora Muntañola (coordinadoras). Representación y cultura audiovisual en la sociedad contemporánea. Barcelona: Editorial UOC.

Génette, Gérard (1982). Palimsestes. La littérature au second degré. París: Seuil.

Goffman, Erving (1991). Los momentos y sus hombres. Barcelona: Paidós.

Guzmán, Alejandro (21 de setiembre del 2010). Entrevista personal. Lima.

Hall, Stuart (2009). Sin garantías. Lima: Universidad Andina Simón Bolívar, Sede Ecuador / Instituto de Estudios Sociales y Culturales Pensar / Pontificia Universidad Javeriana / Instituto de Estudios Peruanos / Envión Editores.

Harvey, David (2004). La condición de la posmodernidad. Investigación sobre los 
orígenes del cambio cultural. Buenos Aires: Amorrortu.

Hevia, Julio (25 de agosto del 2010). Entrevista personal. Lima.

Pospost. «Con Magaly Solier, la publicidad se atreve a cambiar». Pospost [blog]. <http://pospost.blogspot. com/2009/03/con-magaly-solier-lapublicidad-peruana.html>. [Consulta: 14 de julio del 2012].

Said, Edward (2004). El mundo, el texto y el crítico. Barcelona: DeBolsillo.
Sibilia, P. (2008). La intimidad como espectáculo. Buenos Aires: Fondo de Cultura Económica.

Solier, Magaly (15 de octubre de 2010). Entrevista, emitida en el programa El placer de los ojos, producido por TVPerú. Lima.

YouTube. «Spot publicitario de Nescafé con Magaly Solier». Video. $<$ http://www.youtube.com/watch? $\mathrm{v}=22 \mathrm{fEUpvA} 2 \mathrm{BU}>$. [Consulta: $14 \mathrm{de}$ julio del 2012]. 